\title{
Thoughts on Improving the Teaching of Economics in Teaching-oriented Colleges and Universities
}

\author{
Hu Zhangming \\ Guangdong Youth Vocational College, 510507 \\ Item Number: CQ20160407
}

\begin{abstract}
Keywords: Teaching-Oriented Colleges; Economics Teaching; Existing Problems; Improvement Measures
\end{abstract}

\begin{abstract}
Mastering basic knowledge and cultivating applied economic talents is the main goal of teaching-oriented universities in economics teaching. Therefore, in the economics teaching at the undergraduate level, it should be close to reality and cultivate students' practical application ability. This paper puts forward some general problems in the teaching of economics for undergraduates in current teaching universities, and analyzes and thinks about these problems in depth, and proposes relevant improvement strategies, hoping to transform economics for teaching universities and provides some opinions for reference.
\end{abstract}

\section{Introduction}

From the perspective of training objectives, China's colleges and universities can be divided into research-oriented universities that focus on cultivating theoretical and theoretical application of composite talents, and research-based teaching or teaching research based on cultivating theory and applying compound talents. Universities, three types of teaching-oriented colleges that focus on cultivating applied talents. These types of colleges and universities have a clear direction of running schools and training goals, and each has its own development characteristics. Among them, the economics major in teaching-oriented universities cultivates applied economics talents who can adapt to the needs of society. After the author's investigation and research, it is found that there are still some problems in the economics teaching of teaching-oriented universities, and it is necessary to take relevant measures to make adjustments and improvements so as to be able to catch up with the pace of social development in time, so that students can better use the professional skills to serve the community.

\section{Problems in Teaching of Economics in Teaching-oriented Universities}

\subsection{Unreasonable Curriculum}

At present, teaching-oriented colleges pay much attention to the teaching and infiltration of Western theories in the teaching content of economics, but rarely involve Chinese traditional economic theories. There are very few knowledge and teachings on Chinese economic theory. Even the full use of Western theoretical ideas has neglected the involvement of political economics related to China's reform and development. In addition, some colleges and universities do not attach importance to economics courses, and completely adopt the teaching methods of political classes instead of economics teaching. In the process of teaching, individual teachers completely copy the Western theoretical ideas, or promote the informal thoughts, models, conclusions, etc. of some schools, leading students to distinguish between right and wrong, cognitive problems or related theories are too one-sided. The knowledge that students have learned is not in line with reality, and cannot be related to reality. Students cannot correctly understand knowledge and use it in real life.

\subsection{Single Teaching Method}

Through the author's investigation and research, it is found that many colleges and universities still use traditional indoctrination teaching methods in economics teaching. Teachers occupy the leadership of the classroom and instill the theoretical knowledge into the students, but they cannot 
practice the student-centered approach. The teaching philosophy, returning the classroom to the students, leaving students with time to understand, digest, and absorb knowledge, which seriously affects the students' ability to analyze problems and solve problems. The economics major belongs to the social sciences, and there is no way to use the same conditions for repeated experiments. In addition, scholars have different theoretical views, so there have been many schools, many of which are inconsistent with reality, and their theories cannot even be established. If teachers teach knowledge based on these theories, it is difficult to relate to reality. It is precisely because the connection is very difficult, the teacher chooses the traditional teaching method, and inculcates the knowledge of the students. This often makes the classroom monotonous and boring, which makes the students lose interest in learning. Passive learning cannot stimulate students' problems. In the long run, students cannot analyze problems, think about problems, and solve problems independently. They also lack the ability to treat problems in a dialectical manner. Ultimately, they will not be able to grow and adapt to the needs of society for applied economic talents.

\subsection{Lack of Systematic Content}

The most serious problem that the current educational colleges have in the teaching of economics is that their teaching content is not systematic. The various courses of colleges and universities are self-contained, and the relevant links between the curriculum and the curriculum are lost. The teachers only transmit relevant ideological theories in their own classes and carry out teaching, while ignoring the connection of the curriculum itself, ignoring the teaching communication between teachers, which led to conflicting curriculum theories. [1] For example, Western economics and political economics are basic theoretical courses for economics students in teaching universities. However, since both of them involve economics knowledge, they will cause certain conflicts in teaching: In terms of the theoretical background of the course, the difference between the two is still relatively obvious. Therefore, the teacher cannot realize the consistency of the concept when expounding the relevant theories. There may be contradictions in some aspects, which makes the students unable to fully understand the relevant theories. The cognition of concept is unclear, affecting students' emotions, and stimulating students' enthusiasm for learning, which in turn affects the overall learning effect.

\section{Improvement Measures}

\subsection{Reasonable Setting of Course Content}

In order to solve the problem of confusion between economic teaching and political teaching, teachers must inherit and innovate Marxist economics in the process of teaching. On this basis, combine Chinese economic theory and practice with Western economics. The integration of the course content and the systematic setting of theoretical teaching and realistic analysis make the economics teaching more mature. In addition, teachers should reasonably formulate teaching plans on labor theory of value, monetary theory and value law, so that students can understand the essence of value; and optimize the teaching content of labor commodity and surplus value theory, so that students can fully feel the essence of capital; The teaching of the theory of capital accumulation and organic composition of capital can not be ignored, allowing students to fully understand the relationship between value, surplus value and capital accumulation. Reasonable setting of course content is essential for absorbing theoretical knowledge of economics [2].

\subsection{Diversified Teaching Methods}

College teaching must reflect the characteristics of diversified teaching methods. Only by changing the existing teacher-led teaching model, actively implementing heuristic teaching, fully mobilizing students' autonomy and subjective consciousness, guiding students to actively think about problems, actively applying theory, and actively solving problems can stimulate students' thinking. Improve the ability to solve problems. In addition, we must vigorously implement case teaching, turning empty and large theoretical teaching into case analysis close to life reality, so that 
students can more easily understand the connotation of theoretical knowledge, better carry out practical operations, and adapt to society's application-oriented economy and the needs of talent. [3] In this process, teachers must grasp the time allocation of theoretical teaching and case teaching. After explaining the theoretical knowledge, it is necessary to set aside time for case analysis and problem discussion so that students can master the content and apply it in time.

\subsection{Improve Teaching Content and Add Evaluation System}

In view of the lack of systematic problems in teaching content, colleges and universities can improve the teaching content according to their own situation, and add some evaluation systems related to teaching. For example, in the examination process of economics students, the ability to test students' ability to use the relevant theoretical knowledge and analyze and solve problems can be added to the test paper. Teachers can learn the mastery of professional knowledge based on this. In addition, in the usual classroom, teachers can also set questions to ask students questions, and can also arrange related coursework, which is a basis for teachers to evaluate students' knowledge and skills. Teachers should regard the long-term effect of economics teaching as the center of teaching, based on this to improve the content of relevant teaching, and at the same time add an evaluation system that can be used to measure the long-term effects of teaching, focusing on the development goals of teaching-oriented universities. Focus on assessing the overall teaching level and teaching effects of economics teaching for a long time, so as to provide a clear guide for seeing the lack of teaching and positive improvement [4].

\section{Conclusion}

In summary, in order to enable students majoring in economics to achieve good learning outcomes in the process of learning, they can adapt to the needs of current social development in a timely manner, and can meet the needs of society for applied economic talents. Improvements in methods and content are imperative to do. This paper analyzes the problems in the teaching of economics in teaching, such as irrational curriculum, single teaching method, and lack of systematic teaching content. It puts forward the rational setting of course content, diversified teaching methods, perfecting teaching content and adding evaluation. The system and other related improvement measures, in order to further improve the quality of teaching in schools, achieve good teaching results, and fully mobilize the initiative and subjective awareness of students, actively explore knowledge, thereby improving their professional skills, better apply skills and serve the community.

\section{Acknowledgments}

Project Name: "Construction Project of Commercial and Public Training Center Based on the Integration of General Capabilities of Enterprise Management"

\section{References}

[1] Han Songhua. Exploring the Innovative Teaching Methods of Economics in Colleges and Universities[J]. Contemporary Education Practice and Teaching Research (Electronics), 2017, (11): 403.

[2] Zhou Yan. Analysis on the Reform Path of Economics Teaching in Colleges and Universities [J]. Business, 2016, (31): 197-198.

[3] Zheng Meihua. Research on the Teaching Reform of the Western Economics in the Economics of Colleges and Universities[J].High Teaching Journal,2017,(16):135-137.

[4] Lu Jian, Wang Yinhua, Zhang Xiaofang, et al. Teaching practice and thinking of undergraduates' "economics" course in non-administration majors [J]. Journal of Hebei Agricultural University (Agricultural and Forestry Education Edition), 2017, (2): 72-74 , 79. 